\title{
DETERMINAN KETERLAMBATAN PERKEMBANGAN BALITA DI WILAYAH PUSKESMAS ALALAK TENGAH KECAMATAN BANJARMASIN UTARA TAHUN 2018
}

\author{
Hapisah ${ }^{1}$, Rusmilawaty $^{2}$, Rafidah $^{3}$ \\ 1,2,3 Jurusan Kebidanan Poltekkes Kemenkes Banjarmasin \\ Jl. H. Mistarcokrukusoma No. 1 A. Kel. Se Besar. Banjarbaru. Kal-sel, Indonesia \\ Email: hapisah74@gmail.com
}

\begin{abstract}
ABSTRAK : Masa balita merupakan periode terpenting tumbuh kembang, Banyak faktor yang mempengaruhi gangguan keterlambatan perkembangan dapat dideteksi dengan menggunakan Kuesioner Praskrining Perkembangan (KPSP). Hasil wawancara 6 ibu didapatkan 3 tidak diberikan ASI eksklusif, 1 dengan BGM. Dari 6 anak tersebut 2 anak memiliki perkembangan motorik kasar tidak sesuai usia yaitu 1 anak berusia 8 bulan tidak mampu merangkak dan tidak mampu berdiri dari posisi duduk atau posisi merangkak dan 1 anak lainnya berusia 9 bulan tidak mampu melangkah dengan berpegangan dan menyusuri meja.

Desain penelitian menggunakan rancangan matched case control study. Populasi seluruh balita di wilayah Puskesmas Alalak Tengah Kecamatan Banjarmasin Utara sebanyak 3.321 . Sampel kasus adalah bayi yang mengalami keterlambatan perkembangan sebanyak 36 dan kelompok kontrol yaitu bayi yang tidak mengalami keterlambatan perkembangan sebanyak 36 . Analisis bivariabel menggunakan chi square dan analisis multivariable menggunakan Regresi Linear Berganda.

Hasil sebanyak 36 kasus keterlambatan perkembangan balita terdiri dari meragukan 23 orang $(31,9 \%)$ dan penyimpangan 13 orang $(18,0 \%)$. Faktor risiko yang bermakna adalah status gizi $(p=004)$ dengan nilai $\mathrm{OR}=4,8$, stimulasi $(p=003)$ dengan nilai $\mathrm{OR}=5,18$ dan pendapatan orang tua $(p=002)$ dengan nilai $\mathrm{OR}=3,5$. Sedangkan berat badan lahir $(\rho=0,078)$, riwayat pemberian ASI $(\rho=0,227)$, pendidikan $(\rho=0,197)$, pekerjaan $(\rho=0,484)$, jenis kelamin $(\rho=0,401)$ dan jumah saudara $(\rho=0,148)$ tidak ada pengaruh pada keterlambatan perkembangan balita di Puskesmas Alalak Tengah Kecamatan Banjarmasin. Status gizi buruk memilki angka risiko 4,8 paling tinggi di bandingkan dengan determinan lainnya yang mempengaruhi keterlambatan perkembangan balita.
\end{abstract}

Kata Kunci : Determinan Keterlambatan Perkembangan 


\section{PENDAHULUAN}

Salah satu upaya pembangunan kesehatan diselenggarakan melalui upaya kesehatan anak yang dilakukan sedini mungkin sejak anak masih di dalam kandungan. Upaya kesehatan tersebut ditujukan untuk mempertahankan kelangsungan hidupnya sekaligus meningkatkan kualitas hidup anak agar mencapai pertumbuh dan perkembangan optimal baik fisik, mental, emosional maupun sosial (Kementrian Kesehatan RI, 2013).

Pada dasarnya setiap anak akan melewati proses pertumbuhan dan perkembangan sesuai tahapan usianya terlebih pada masa lima tahun pertama kehidupan (masa balita). Masa balita merupakan periode terpenting dalam tumbuh kembang, karena pada masa ini pertumbuhan dasar akan mempengaruhi dan menetukan perkembangan balita selanjutnya, masa ini disebut juga sebagai "masa keemasan" (golden period), "jendela kesempatan" (window of opportunity), dan "masa kritis" (critical period) yang berlangung sangat pendek serta tidak dapat diulang lagi (Andriana, 2011).

Berdasarkan profil kesehatan (2016) estimasi jumlah Balita di Indonesia sangat besar yaitu sekitar $9 \%$ dari seluruh populasi, maka sebagai calon generasi penerus bangsa, kualitas tumbuh kembang balita perlu mendapat perhatian serius yaitu mendapat gizi yang baik, stimulasi yang memadai serta terjangkau oleh pelayanan kesehatan berkualitas termasuk deteksi dan intervensi dini penyimpangan terhadap perkembangan (Kemenkes RI, 2016).

Perkembangan adalah bertambahnya kemampuan (skill) dalam struktur dan fungsi tubuh yang lebih kompleks dalam pola yang teratur serta dapat diramalkan sebagai hasil dari proses pematangan. Perkembangan anak selalu mengikuti pola yang teratur dan berurutan, tahap- tahap tersebut tidak bisa berbalik, misalnya anak lebih dahulu mampu berdiri sebelum berjalan, perkembangan berlangsung dari tahapan umum ke tahapan spesifik dan terjadi kesinambungan(Soetjiningsih dan Ranuh2014).

Masa kritis perkembangan dialami dalam lima tahun pertama kehidupan seorang anak karena pada masa ini terbentuknya dasar-dasar kepribadian manusia,kemampuan pengindraan, berpikir, ketrampilan berbahasa, berbicara, bertingkah laku sosial dan sebagainya. Dari penelitian yang berkaitan dengan masalah perkembangan di Indonesia menunjukkan data adanya gangguan perkembangan terjadi antara 13\%18\%.berdasarkan hasil peneliti Meita (2006) menggunakan Kuesioner Praskrining Perkembangan (KPSP) didapatkan dugaan balita mengalami gangguan perkembangan sebayak 15\%. (Direktorat Bina Kesehatan Keluarga, 1998: Meita, 2006: Depkes RI, 2012).

Banyak faktor yang mempengaruhi proses perkembangan diantaranya adalah faktor lingkungan biologis setelah anak dilahirkan yaitu ras/suku bangsa, jenis kelamin, umur, status gizi, perawatan kesehatan, penyakit kronis, fungsi metabolisme, dan hormon. Kemampuan motorik anak usia 12-18 bulan di keluarga miskin dan tidak miskin di Ciomas Bogor berhubungan signifikan dengan faktor kecukupan energi, kecukupan protein, dan aktivitas anak. Sedangkan lingkungan fisik antara lain cuaca, sanitasi, keadaan rumah dan radiasi ( Puslitbang gizi dan makanan, 2001).

Faktor psikososial juga sangat berpengaruh terhadap perkembangan anak diantaranya adalah stimulus orang tua, pekerjaaan dan pendidikan ibu. Anak yang 
mendapatkan stimulasi yang terarah dan teratur akan lebih cepat berkembang dibandingkan dengan anak yang kurang mendapat stimulasi. Kualitas stimulasi dalam lingkungan keluarga berhubungan dengan perkembangan kognitif anak. Selain itu faktor lain yang berpengaruh terhadap perkembangan kognitif anak adalah pekerjaan dan tingkat pendidikan ibu (Soetjiningsih, 2012; Andrade et al., 2005).

Selain faktor diatas, faktor keluarga dan adat istiadat diantaranya pekerjaan, pendapatan keluarga, pendidikan orang tua, jumlah saudara dan jenis kelamin.riwayat perinatal (prematuritas, BBLR, gemelli dan komplikasi persalinan) dan praktik pemberian makanan. Hasil penelitian bahwa menyusui dapat memberikan perlindungan terhadap keterlambatan perkembangan motorik halus dan kasar pada anak usia 9-18 bulan ibu (Soetjiningsih, 2011; Sacker et al., 2006).

Salah satu alat yang bisa digunakan untuk menilai perkembangan anak secara dini adalah dengan menggunakan Kuesioner Pra Skrining Perkembangan (KPSP). Kuesioner ini direkomendasikan oleh Depkes RI untuk digunakan di tingkat pelayanan kesehatan primer sebagai salah satu upaya deteksi dini tumbuh kembang anak dengan dipilih 10 pertanyaan sesuai dengan umur anak dan dinilai berdasarkan kriteria yang sudah ditentukan (Departemen Kesehatan [Depkes], 2006).

Berdasarkan studi pendahuluan pada bulan Agustus 2017 di Dinas Kesehatan Provinsi Kalimantan Selatan, keterlambatan perkembangan balita belum ada data yang menunjukan besar persentasinya akan tetapi berdasarkan regester dari kunjungan balita yang di rujuk ke Rumah Sakit Ulin Banjarmasin Wilayah Puskesmas Kecamatan Banjarmasin Utara cukup mendominasi dari seluruh kunjungan balita ke poli klinik tumbuh kembang. Hasil wawancara di salah satu Puskesmas Alalak Tengah Kecamatan Banjarmasin Utara terhadap 6 orang ibu yang diantaranya 3 orang tidak memberikan ASI eksklusif, 1 orang dengan BGM dengan umur yang berbeda-beda dari 6-12 bulan didapatkan hasil 2 diantaranya memiliki perkembangan motorik kasar tidak sesuai usia yaitu 1 anak yang diberikan ASI ekslusif berusia 8 bulan tidak mampu merangkak dan tidak mampu mulai berdiri dari posisi duduk atau posisi merangkak dan 1 anak lagi tidak diberikan ASI berusia 9 bulan tidak mampu melangkah dengan berpegangan dan menyusuri meja.

Berdasarkan latar belakang yang telah diuraikan dan menyadari pentingnya perkembangan anak balita, maka penulis tertarik untuk melakukan penelitian yang berjudul "Determinan Keterlambatan Perkembangan Balita di Wilayah Puskesmas Alalak Tengah Kecamatan Banjarmasin Utara Tahun 2018".

\section{BAHAN DAN METODE}

Desain penelitian menggunakan observasional, dengan rancangan matched case control study melalui pendekatan kuantitatif.. Penelitian dilaksanakan di Wilayah Puskesmas Alalak Tengah Kecamatan Banjarmasin Utara Tahun 2019. Populasi dari penelitian ini adalah seluruh balita di wilayah Puskesmas Alalak Tengah Kecamatan Banjarmasin Utara yaitu sebanyak 3.321 orang. Sampel kasus adalah bayi yang mengalami keterlambatan perkembangan sebanyak 36 orang dan kelompok kontrol yaitu bayi yang tidak mengalami keterlambatan perkembangan sebanyak 36 orang yang memenuhi kriteria inklusi dan eksklusi. Tehnik pengambilan sampel kasus adalah dengan non probability sampling dengan metode consecutive sampling. 
Instrumen penelitian menggunakan Angket/kuesioner, KMS, Kuesioner Pra Skrining Perkembangan (KPSP). Teknik pengambilan Pengumpulan data penelitian dilakukan dengan menggunakan data primer dan data sekunder.

Analisis yang digunakan analisis univariabel, analisis bivariabel dengan uji statistik menggunakan chi square, Uji normalitas data menggunakan uji Shapiro-Wilk dan dengan uji statistik menggunakan Regresi Linear Berganda.

\section{HASIL DAN PEMBAHASAN}

Tabel 4.3 Distribusi Variable Penelitian pada Kasus dan Kontrol di Puskesmas Alalak Tengah Tahun 2018

\begin{tabular}{|c|c|c|c|c|c|c|}
\hline \multirow{2}{*}{ Variabel } & \multicolumn{2}{|c|}{ Kasus } & \multicolumn{2}{|c|}{ Kontrol } & \multicolumn{2}{|c|}{ Jumlah } \\
\hline & $\mathrm{n}=36$ & $(\%)$ & $\mathrm{n}=36$ & $(\%)$ & $\mathrm{N}=72$ & $(\%)$ \\
\hline \multicolumn{7}{|l|}{ Status gizi } \\
\hline Baik & 16 & 44.4 & 28.0 & 77.8 & 44 & 61.1 \\
\hline Kurang & 20 & 55.6 & 8.0 & 22.2 & 28 & 38.9 \\
\hline \multicolumn{7}{|l|}{ Stimulasi } \\
\hline Baik & 25 & 69.4 & 33.0 & 91.7 & 58 & 80.6 \\
\hline Kurang & 11 & 30.6 & 3.0 & 8.3 & 14 & 19.4 \\
\hline \multicolumn{7}{|c|}{ Pendapatan keluarga } \\
\hline$\geq$ UMR & 15 & 41.7 & 25.0 & 69.4 & 40 & 55.6 \\
\hline$<$ UMR & 21 & 58.3 & 11.0 & 30.6 & 32 & 44.4 \\
\hline \multicolumn{7}{|l|}{ Riwayat BBLR } \\
\hline Tidak & 27 & 75.0 & 28.0 & 77.8 & 55 & 76.4 \\
\hline $\mathrm{Ya}$ & 9 & 25.0 & 8.0 & 22.2 & 17 & 23.6 \\
\hline \multicolumn{7}{|c|}{$\begin{array}{l}\text { Riwayat Pemberian } \\
\text { ASI }\end{array}$} \\
\hline Eksklusif & 25 & 69.4 & 22.0 & 61.1 & 47 & 65.3 \\
\hline Tidak ekslusif & 11 & 30.6 & 14.0 & 38.9 & 25 & 34.7 \\
\hline \multicolumn{7}{|c|}{ Pendidikan orang tua } \\
\hline Tinggi & 3 & 8.3 & 7.0 & 19.4 & 10 & 13.9 \\
\hline Dasar & 33 & 91.7 & 29.0 & 80.6 & 62 & 86.1 \\
\hline \multicolumn{7}{|c|}{ Pekerjaan orang tua } \\
\hline Tidak bekerja & 2 & 5.6 & 1.0 & 2.8 & 3 & 4.2 \\
\hline $\begin{array}{l}\text { Bekerja } \\
\text { Jenis Kelamin }\end{array}$ & 34 & 94.4 & 35.0 & 97.2 & 69 & 95.8 \\
\hline Perempuan & 20 & 55.6 & 20.0 & 55.6 & 40 & 55.6 \\
\hline Laki-laki & 16 & 44.4 & 16.0 & 44.4 & 32 & 44.4 \\
\hline \multicolumn{7}{|l|}{ Jumlah Saudara } \\
\hline Sedikit & 29 & 80.6 & 21.0 & 58.3 & 50 & 69.4 \\
\hline Banyak & 7 & 19.4 & 15.0 & 41.7 & 22 & 30.6 \\
\hline
\end{tabular}

Tabel 4.4Analisis Regresi Linear Berganda Variabel Penelitian pada Kasus dan Kontrol di Puskesmas Alalak Tengah Tahun 2018

\begin{tabular}{|c|c|c|c|c|c|}
\hline \multirow{2}{*}{ Variabel } & Kasus & Kontrol & \multirow[b]{2}{*}{ OR } & \multirow[b]{2}{*}{ Cl 95\% } & \multirow[b]{2}{*}{$P$} \\
\hline & $\begin{array}{cc}n=3 \\
6\end{array}$ & $\begin{array}{cc}n=3 \\
6\end{array}$ & & & \\
\hline
\end{tabular}




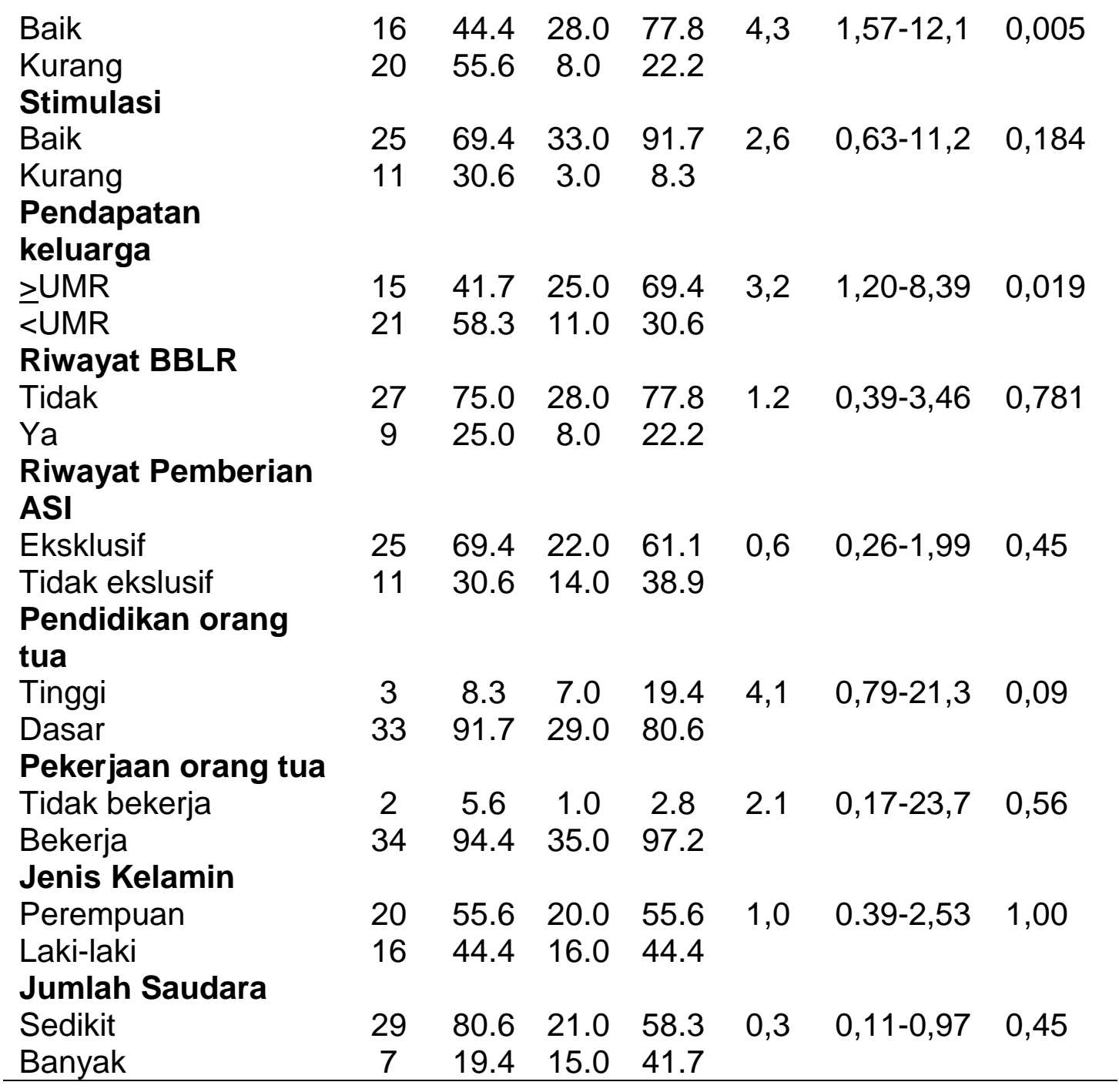

Tabel 4.5 Hasil Akhir Analisis Regresi Linear Berganda Variabel Penelitian pada Kasus dan Kontrol di Puskesmas Alalak Tengah Tahun 2018

\begin{tabular}{cccccccc}
\hline $\begin{array}{c}\text { Sub } \\
\text { Variabel }\end{array}$ & B & S.E & Wald & df & $\begin{array}{c}\boldsymbol{P} \\
\text { Value }\end{array}$ & Exp(B) & 95\% C.I \\
\hline Status Gizi & 1.476 & 0.523 & 7.937 & 1 & 0.005 & 4.8 & $1,57-12,1$ \\
\hline Pendidikan & 1.412 & 0.841 & 2.820 & 1 & 0.093 & 4.1 & $0,79-21,3$ \\
\hline Pendapatan & 1.157 & 0.496 & 5.464 & 1 & 0.019 & 3.1 & $1,20-8,39$ \\
\hline Stimulasi & 0.977 & 0.736 & 1.763 & 1 & 0.184 & 2.6 & $0,63-11,2$ \\
\hline
\end{tabular}

Determinan Keterlambatan Perkembangan Balita di Wilayah Puskesmas Alalak Tengah didapatkan sebanyak 36 orang kasus dan 36 orang kontrol. Penetapan kasus berdasarkan hasil dari pengukuran Praskrining Perkembangan (KPSP) terhadap empat aspek perkembangan yaitu motorik kasar, motorik halus, bicara dan bahasa, serta sosialisasi dan kemandirian. Hasil dari pengukuran KPSP di dapatkan sebanyak 23 orang $(31,9 \%)$ responden dengan keterlambatan meragukan dan 18 orang $(18,1 \%)$ responden dengan perkembangan penyimpangan. 
Berdasarkan tabel akhir 4.5 menunjukan bahwa determinan yang erat mempengaruhi perkembangan balita dan mempunyai peluang yang menjadikan factor terhambatnya perkembangan balita adalah status gizi, pendidikan orang tua, pendapatan orangtua, dan stimulasi terhadap balita tersebut, dari tabel kita juga dapat menyimpulkan bahwa status gizi buruk memilki angka risiko paling tinggi di bandingkan dengan determinan lainnya yang mempengaruhi perkembangan balita.

Berdasarkan tabel 4.4 pada kelompok balita yang mengalami gizi kurang memiliki hubungan yang signifikan terhadap keterlambatan perkembangan balita dengan nilai $p=0,005$ dan OR 4,8 (Cl 1,57-12,1). Risiko Keterlambatan Perkembangan pada balita dengan status gizi kurang memiliki risiko 4,8 kali lebih besar dibanding dengan balita yang memiliki status gizi baik.

Hasil penelitian ini sejalan dengan penelitian yang menyatakan bahwa status gizi kurang berpengaruh terhadap keterlambatan perkembangan anak usia 1-5 tahun ${ }^{1,2}$. Status gizi memiliki pengaruh berbeda pada setiap perkembanganbalita, apabila komsumsi gizi seimbang tidak terpenuhi maka pertumbuhan dan perkembangan motorik akan terhambat dan kecukupan energi, kecukupan protein dan aktivitas anak berpengaruh kemampuan motorik balita khususnya pada usia 12-18 bulan $^{3}$.Balita dengan status gizi kurang/buruk memiliki risiko 5,9 kali lebih besar mengalami keterlambatan pertumbuhan dan perkembangan motorik dibandingkanbalita dengan status gizi baik ${ }^{4}$.

Prevalensi gizi kurang dan buruk yang tinggi berdampak pada terjadinya stunting pada balita. Tiga faktor utama penyebab gizi kurang, yaitu kualitas dari kuantitas konsumsi pangan yang buruk, pola asuh, dan akses fasilitas kesehatan yang tidak memadai ${ }^{5}$. Nutrisi merupakan salah satu komponen yang penting dalam menunjang keberlangsungan proses pertumbuhan dan perkembangan ${ }^{6}$. Keadaan gizi kurang dapat mengakibatkan perubahan struktur dan fungsi otak pada minggu ke-24-42 setelah konsepsi dan berlanjut hingga usia 2 atau 3 tahun, periode tercepat usia 6 bulan pertama kehidupan ${ }^{7}$. Dengan demikian pertumbuhan sel otak berlangsungsampai usia 3 tahun. Kekurangan gizi pada usia di bawah 2 tahunakan menyebabkan sel otak berkurang $15 \%-20 \%$, sehingga anak kelak di kemudian hari mempunyai kualitas otak sekitar 80\%-85\%.Apabila otak tidak berkembang secara optimal maka akan berpengaruhi perkembangan kognitif anak yang meliputi kemampuan memahami dunianya melalui inderanya, kecakapan motorik dan proses berfikir logis maupun abstrak. Kondisi inilah yang menjadi faktor penyebab gangguan pertumbuhan dan perkembangan pada seorang balita .

Hasil penelitian yang terdapat pada 4.4 Stimulasi juga memiliki hubungan yang signifikan terhadap keterlambatan perkembangan balita dengan nilai $p=$ 0,018 dan OR 2,6 (0,63-11,2). Hasil penelitian menunjukkan bahwa balita dengan stimulasi kurang memiliki risiko 2,6 kali lebih besar mengalami keterlambaan perkembangan dibanding dengan balita yang diberikan stimulasi baik. Hal ini sesuai dengan teori yang menyatakan, bahwa stimulasi yang diberikan orang tua mempunyai peranan penting dalam perkembangan seorang anak balita ${ }^{8}$. Stimulasi adalah perangsangan (penglihatan, bicara, pendengaran, perabaan) dan latihanlatihan terhadap kepandaian anak yang datangnya dari lingkungan luar anak.Stimulasi perkembangan anak diberikan setiap saat, sesering mungkin, sesuai dengan umur dan kesiapan anak.Stimulasi visual (penglihatan), verbal (bicara), auditif (pendengaran), taktil (sentuhan) dll dapat dapat diberikan setiap hari dan bila anak mengalami keterlambatan, stimulasi diberikan setiap hari selama 3-4 jam $^{9,10}$.

Faktor lain yang mempengaruhi pertumbuhan dan perkembangan adalah pendapatan keluarga. Pendapat keluarga merupakan salah satu faktor yang dapat 
mempengaruhi perkembangan anakterutama pada perkembangan kecerdasan. Hal ini kemungkinanberpengaruh pada keterbatasankeluarga dalam menyediakan kebutuhan makan yang memenuhi gizi seimbang dan berbagai fasilitas bermain sehingga anak kurang mendapat stimulasi.Hasil penelitian pada tabel 4.4 menggambarkan bahwa terdapat hubungan yang bermakna antara pendapatan keluarga terhadap keterlambatan perkembangan balitadengan nilai $p=0,019$ dan OR 3,1. Risiko keterlambatan perkembangan balita 3,1 kali lebih besar pada pendapatan keluarga < UMR dibanding dengan balita yang memiliki pendapatan keluarga $>$ UMR.

Pendapatan keluarga mempunyai pengaruh terhadap perkembangan balita dikuatkan dengan penelitian Guttmann et al., (2004) yang menyatakan faktor yang mempengaruhi buruknya pencapaian perkembangan anak prasekolah adalah keluarga dengan pendapatan yang rendah ${ }^{11}$. Hasil penelitian ini tidak sejalan dengan penelitian yang dilakukan oleh Solechah (2017) bahwa pendapatan keluarga tidak memiliki hubungan bermakna terhadap keterlambatan perkembangan ${ }^{12}$.

Pendidikan orang tua secara statistik menunjukkan hubungan yang bermakna dengan keterlambatan perkembangan balita dengan nilai $p=0,093$, secara praktis pendidikan dasar dapat meningkatkan kejadian keterlambatan perkembangan balita 4,5 kali dibanding dengan pendidikan orang tua tinggi. Pendidikan orang tua berpengaruh terhadap perkembangan anak terutama pendidikan ibu.Pendidikan ibu yang rendah mempunyai risiko untuk terjadinya keterlambatan perkembangan anak, disebabkan ibu belum tahu cara dan manfaat memberikan stimulasi perkembangan anaknya. Ibu dengan pendidikan lebih tinggi lebih terbuka untuk mendapat informasi dariluar tentang cara pengasuhan anak yang baik, menjagakesehatan, dan pendidikan anak. Penelitia dari...juga menyatakan Ibu dengan tingkat pendidikan rendah lebih sulit menerima informasi daripada ibu dengan tingkat pendidikan tinggi ${ }^{13}$.

Hasil penelitian menunjukkan bahwa riwayat lahir BBLR tidak memiliki hubungan yang signifikan terhadap keterlambatan perkembangan balita dengan nilai $p=0,78$ namun secara praktis bayi BBLR mempunyai risiko 1,2 kali lebih tinggi mengalami keterlambatan perkembangan dibanding dengan riwayat lahir normal. Hasil tersebut tidak sesuai dengan penelitian sejnis yang dilakukan sebelumnya.Hasil penelitian lain mengatakan bahwa kejadian BBLR berdampak terhadap rendahnya kemampuan perkembangan anak di usia 15 dan 24 bulan dibandingkan anak yang dilahirkan dengan berat normal ${ }^{14}$.

Bayi Berat Lahir Rendah (BBLR) rentan terhadap ketidaknormalan tanda-anda neurologis, koordinasi, dan reflek. Adanya komplikasi neonatal pada bayi BBLR menyebabkan adanya gangguan dalam perkembangan motorik yang akan mempengaruhi fungsi pergerakan organ tubuh. Bayi dengan Berat Badan Lahir Rendah (BBLR) mengalami defisit sel otak dan simpanan zat gizi sehingga mudah sakit dan membutuhkan waktu lebih lama dalam perkembangan, mengalami kesulitan belajar, gangguan fungsi otak, gangguan kesehatan mental serta masalah tumbuh kembang lainnya.

Hasil penelitian menunjukkan bahwa $76,4 \%$ balita lahir dengan riwayat BBLN akan tetapi didapatkan sebanyak $74,3 \%$ kasus yang mengalami keterlambatan perkembangan dan hanya $25,7 \%$ kasus BBLR mengalami keterlambatan perkembangan. Hal ini dapat terjadi karena perawatan setelah kelahiran yang baik yang dapat meminimalkan adanya gangguan pertumbuhan dan mencegah adanya gangguan neonatalyang berpengaruh terhadap keterlambatan merangsang 
perkembangan motorik bayi dengan BBLR sehingga tidak mengalami keterlambatan perkembangan.

Menurut Lisa (2012) ASI mengandung gizi yang tinggi, juga adanya zat anti pada ASI yang melindungi bayi terhadap berbagaimacam infeksi. Disamping itu memberikan stimulasi karena bayi juga merasakan sentuhan, kata-kata dan tatapan kasih sayang dariibunya, serta mendapatkan kehangatan yang penting untuk tumbuh kembangnya. Sedangkan pemberian ASI tidak eksklusif berisiko 5,6 kali terjadi ketidaksesuaian perkembangan motorik kasar balita dibandingkan dengan balita yang diberi ASI eksklusi ${ }^{15}$. Hasil penelitian menunjukkan hasil yang berbeda, balita dengan riwayat pemberian ASI tidak ekslusif, secara statistik tidak menunjukkan hubungan yang signifikan dengan keterlambatan perkembangan balita dengan nilai $p=0,45$.

Untuk mendapatkan pertumbuhan yang optimal tidak cukup faktor ASI saja walaupundi dalam ASI terdapat zat makro maupun zat mikroyang sangat membantu dalam perkembangan balita,tetapisetelah umurbalita melewati 6 bulan ada baiknya, balita diberikan makanan tambahanyang menunjang ASI (MP-ASI) yang dimana hal tersebut akanmemhubungani status gizi balita tergantung dari pemberian asupanmakanan yang bergizi yang diberikan oleh orang tua balita. Meskipun secara statistik tidak didapatkan hubungan antara pemberian ASI eksklusif dengan pertumbuhan, namun peneliti hasil penelitian (tabel 4.3) didapatkan sebanyak $66,6 \%$ balita yang di berikan ASI eksklusif mengalami keterlambatan perkembangan, hal tersebut dapat terjadi karena faktor lain yang kemungkinan sangat berpengaruh diantaranya adalah status gizi, stimulasi dan pendapatan orang tua.

Pada variabel jenis kelamin tidak didapatkan hubungan yang signifikan dengan keterlambatan perkembangan balita dengan nilai $p=1,00$. Hal ini dikuatkan dengan penelitian lain yang menyatakan bahwa faktor yang mempengaruhi buruknya pencapaian perkembangan anak prasekolah adalah oleh jenis kelamin laki-laki.Pada penelitian ini, presentase kasus keterlambatan anak laki-laki dengan anak perempuan hampir sama dengan perbandingan 53,4\% dan 57,7\% ${ }^{11}$. Hal tersebut sesuai dengan pernyataan Soetjiningsih (2015)bahwa anak laki-laki cenderung memiliki sifat agresif dibandingkan anak perempuan.Kecenderungan ini menjadikan anak laki-laki lebih sering mengekspresikan diri secara terbuka tanpa rasa takut dan salah ${ }^{14}$.

Jumlah saudara banyak secara statistik tidak menunjukkan hubungan yang signifikan terhadap keterlambatan perkembangan balita dengan nilai $p=$ 0,45 . Orang tua yang merawat hanya satu anak, akan cenderung lebih fokus dan lebih banyak menstimulasi perkembangannya. Hal ini terjadi pada anak pertama maupun anak tunggal. Pada anak kedua dan seterusnya, perhatian orang tua menjadi kurang fokus terhadap pertumbuhan dan perkembangannya, karena orang tua juga merawat saudara yang lain. Hal ini dapat menjelaskan mengapa anak pertama atau anak tunggal lebih mencegah terjadinya keterlambatan perkembangan global.

\section{KESIMPULAN}

Determinan yang erat mempengaruhi perkembangan balita dan mempunyai peluang yang menjadikan factor terhambatnya perkembangan balita adalah status gizi $(p=0,005)$, pendidikan orang tua $(p=0,093)$, pendapatan orangtua $(p=0,019)$, dan stimulasi terhadap balita $(p=0,018)$. Status gizi buruk memilki angka risiko 4,8 paling 
tinggi di bandingkan dengan determinan lainnya yang mempengaruhi keterlambatan perkembangan balita.

\section{UCAPAN TERIMAKASIH}

Terima kasih Kepada responden dan pihak Puskesmas yang telah memfasilitasi dan bekerja sama untuk skrining yang lebih baik dan perhatian khusus dari ibu untuk asupan gizi, memberikan stimulasi yang sesuai dengan dan memeriksakan ke tenaga kesehatan secara rutin,sehingga deteksi dini pertumbuhan dan perkembangan balitanya dapat terpantau.

\section{DAFTAR PUSTAKA}

1. N. Devi, Nutrition and Food: GiziuntukKeluarga. Jakarta: Kompas, 2010

2. Ending. Hubungan Antara Staus Gizi Dengan Perkembangan Motorik Kasar Anak Usia 1-5 Tahun di Posyandu Buah Hati Ketelan Banjar Sari. Purwakarta. 2012

3. Sitaresmi, MN, Ismail, D, Wahab, A, 'Risk Factor of Developmental Delay: a community-based study, Paediatrica Indonesiana', 2008. vol.48, no.3, pp. 161-165

4. Wiekke $O$. Hubungan status gizi terhadap status perkembangan motorik anak usia 0-3 tahun (BATITA) di Kecamatan Kejayan Kabupaten Pasuruan (Skripsi).Malang: Universitas Muhammadiyah, 2007.

5. Arumsari Dan M.Faizi. Faktor Risiko Yang Berhubungan Dengan Keterlambatan Perkembangan Global Pada Balita.Fakultas Kedokteran Universitas Airlangga Surabaya. 2013

6. Halrunis.NM, et.al. Hubungan Status Gizi dan Stimulasi Tumbuh Kembang dan Perkembangan Balita. Dapertemen IImu Gizi. FK Sebelas Maret.Surakarta. 2019

7. Rosela Entie, et.al. Hubungan Status Gizi Dengan Perkembangan Anak Usia 1 sampai 5 Tahun di Kelurahan Tidar Utara Kota Magelang. Jurnal Keperawatan Soediman. Semarang. 2017.vol. 12 no.1.

8. Michael K, Georgieff MD. The role of ironneurodevelopment : fetal iron deficiency and thedeveloping hippocampus. Biochem Soc Trans; 2008.36:1267-71.

9. Depkes. Pedoman Pelaksanaan Stimulasi, Deteksi dan Intervensi Dini Tumbuh Kembang Anak. Jakarta ; 2005.

10. Soetjiningsih. Tumbuh kembang anak. Jakarta: Penerbit Buku Kedokteran EGC; 2012

11. Andarwati, R. Hubungan antara berat badan lahir, ASI eksklusif, status gizi dan stimulasi kognitif dengan kecerdasan anak usia 5-6 tahun di Kecamatan Prambanan-Sleman.Tesis, Program Pasca Sarjana, Universitas Gadjah Mada. Yogyakarta. 2006

12. Guttmann, A., To, T.. Dick, P.T., Rosenfield, J.D., Parkin, P.C., Tassoudji, M., Vydykhan, T.N., Cao, H. \& Harris, J.K. Risk markers for poor developmental attainment in young children.Arch Pediatr adolesc Med, 2004, 158, 643-49.

13. Solechah.M. Hubungan Status Gizi dengan Perkembangan Balita usia 1-3 tahun di Wilayah Kerja Puskesmas Jetis Kota Yogyakarta. Universitas Aisyiyah Yogyakarta. 2017

14. Lisa, UF. Hubungan Pemberian ASI Eksklusif denganPerkembangan motorik kasar balitadi kelurahan brontokusuman Kecamatan MergangsanYogyakarta.Jurnal ilmiah stikes u'budiyah vol.1, no.2 maret 2012.

15. Soetjiningsih \& Ranuh, G. Tumbuh Kembang Anak. Edisi 2. Jakarta: EGC, 2014.

16. Ni'mah Cholifatmin \& Lailatul Munirah. Hubungan Tingkat Pendidikan, Pengetahuan, dan Pola Asuh dengan Wasting dan Stunting Pada Balita Keluarga Miskin. Dapertemen Gizi Kesehatan. Universitas Airlangga. Surabaya.2015 
17. Arikunto, Suharsimi. Prosedur Penelitian Suatu Pendekatan Praktik. Jakarta: Rineka Cipta, 2010.

18. Dinkes Provinsi Kalsel, Profil Kesehatan 2010, Dinkes Provinsi Kalsel, 2010.

19. Hidayat, Aziz Alimul. Metode Penelitian Kebidanan dan Teknik Analisis Data. Jakarta: Salemba Medika, 2014.

20. Notoatmodjo, Soekidjo. Metodologi Penelitian Kesehatan. Jakarta: Rineka Cipta, 2010 